\section{Effect of Time of Planting, Plant Size, and Nursery-growing Environment on the Performance of 'Festival' Strawberry in a Subtropical Environment}

\author{
C.M. Menzel ${ }^{1}$ and L. Smith
}

ADDITIONAL INDEX WORDs. Fragaria $\times$ ananassa, bare-rooted, propagation, southeastern Queensland

SUMMARY. Experiments were conducted to determine the effect of time of planting, plant size, and nursery-growing environment on the performance of bare-rooted 'Festival' strawberry plants (Fragaria $\times$ ananassa) at Nambour in southeastern Queensland, Australia, over 3 years. Yields were best with a planting in mid-March (1013 g/plant), with lower yields with a planting in early March (711 g/plant), late March/early April (765 g/plant), mid-April (671 g/plant), or late April/early May (542 g/plant). Plants obtained from Stanthorpe in southern Queensland, a warmgrowing environment, were just as productive $(695 \mathrm{~g} / \mathrm{plant})$ as those from Toolangi in Victoria (710 g/plant) or Kempton in Tasmania (701 g/plant), two cool-growing environments. In contrast, large plants from these nurseries with crown diameters ranging from 10 to $17 \mathrm{~mm}$ had $17 \%$ higher yields than small plants with crown diameters ranging from 6 to $10 \mathrm{~mm}(751 \mathrm{vs} .642 \mathrm{~g} / \mathrm{plant})$. These results suggest that planting in mid-March is optimal for 'Festival' in this environment. Lower yields with an earlier planting reflected the small size of the plants, whereas lower yields with later plantings reflected the shorter growing seasons. It can also be concluded that plant size is more important than nurserygrowing environment in determining the productivity of strawberry fields in southeastern Queensland.

$\mathrm{S}$ trawberry production in southeastern Queensland, Australia, is based mainly on short-day cultivars supplied each year as bare-rooted transplants from nurseries at Stanthorpe in southern Queensland or from Toolangi in Victoria (Menzel and Toldi, 2010; Morrison and Herrington, 2002). The main cultivars grown in this area include Festival from Florida (Chandler et al., 2000), Camarosa from California (Hancock, 2008), and Rubygem from Australia (Herrington et al., 2007). The nursery material is planted from late March to early May, although the optimum times of planting for the different cultivars in this warm subtropical environment have not been established. The main harvest lasts from

Department of Employment, Economic Development and Innovation, P.O. Box 5083, SCMC, Nambour, Qld 4560, Australia

We thank Horticulture Australia Limited, Strawberries Australia, the Queensland Strawberry Growers' Association, Florida Strawberry Growers' Association, Sweets Strawberry Runners, Red Jewel Nursery, Toolangi Certified Strawberry Runner Growers' Co-operative, Tasmanian Highland Strawberry Runners, Lauren Stirling, and farm staff at Maroochy Research Station.

'Corresponding author. E-mail: chris.menzel@deedi. qld.gov.au. early June to late October. These times are equivalent to from late September to early November and from early December to late April in Florida in the northern hemisphere.

Mean temperatures during plant growth from January to April in the strawberry nurseries in southern Australia are up to $5^{\circ} \mathrm{C}$ lower compared with the conditions in southern Queensland. There are also differences in photoperiod in these different growing areas, which are likely to affect flowering and fruit production (Durner and Poling, 1988; Durner et al., 1984; Stewart and Folta, 2010). It is not known whether the differences in environmental conditions in the different nursery-growing areas in Australia translate into differences in fruit production when the plants are grown at
Nambour. There is also a large variation in the size of the planting material supplied by the nurseries, but whether large stock is more productive than small stock has not been determined.

The effect of time of planting on the productivity of strawberry has been studied in Florida. This area has a subtropical climate similar to southeastern Queensland, with berries produced from December to April (Peres et al., 2006). The early studies in Florida focused on plants obtained from local nurseries at lower elevation, whereas the later work included the response of plants from northern nurseries located at higher latitudes or at higher elevations. The material was planted from September to November, with material planted in October generally providing the best yields or returns (Albregts and Chandler, 1994; Albregts and Howard, 1974, 1977; Chandler et al., 1991; Duval et al., 2005; Locascio, 1972).

An analysis of the effect of nurserygrowing environment on the performance of strawberry in Florida shows that plants from northern or midlatitude nurseries (Canada, Massachusetts, Oregon, California, or North Carolina) out-yielded those from southern nurseries (Alabama or Florida) in about half the cases (Albregts and Chandler, 1994; Albregts and Howard, 1974; Chandler et al., 1989; Stapleton et al., 2001). The temperatures in these northern areas are up to $10^{\circ} \mathrm{C}$ lower than those in Florida during the 6 to 8 weeks before the plants are dug (Chandler et al., 1989). There are also differences in photoperiod among the different nurserygrowing areas in the United States and Canada, which are likely to affect production (Durner and Poling, 1988; Durner et al., 1984).

Bish et al. (1997) examined the performance of different sized barerooted plants of 'Sweet Charlie' in Florida. The plants were obtained from Massachusetts or Florida and divided into three groups with crown diameters of 8,12 , or $16 \mathrm{~mm}$. There were

\begin{tabular}{llll}
\hline $\begin{array}{l}\text { Units } \\
\text { To convert U.S. to SI, } \\
\text { multiply by }\end{array}$ & U.S. unit & SI unit & $\begin{array}{l}\text { To convert SI to U.S., } \\
\text { multiply by }\end{array}$ \\
\hline 0.3048 & $\mathrm{ft}$ & $\mathrm{m}$ & 3.2808 \\
25.4 & inch $(\mathrm{es})$ & $\mathrm{mm}$ & 0.0394 \\
6.4516 & inch $^{2}$ & $\mathrm{~cm}^{2}$ & 0.1550 \\
0.2276 & inch $^{2} / \mathrm{oz}$ & $\mathrm{cm}^{2} \cdot \mathrm{g}^{-1}$ & 4.3942 \\
28.3495 & $\mathrm{OZ}$ & $\mathrm{G}$ & 0.0353 \\
$\left({ }^{\circ} \mathrm{F}-32\right) \div 1.8$ & ${ }^{\circ} \mathrm{F}$ & ${ }^{\circ} \mathrm{C}$ & $\left(1.8 \times{ }^{\circ} \mathrm{C}\right)+32$ \\
& & &
\end{tabular}


small differences in the cropping pattern among the three groups of plants, with slightly heavier production in the small or large plants in individual months between November and February, but no differences in total production.

We report on the effect of time of planting, plant size, and nursery-growing environment on the performance of 'Festival' strawberry in southeastern Queensland over 3 years. First, barerooted plants were obtained from Stanthorpe in southern Queensland and planted at Nambour from early March to early May. We were interested in determining how the time of planting affected the relationship between yield and plant growth in this environment. We proposed that low yields with an early planting might be related to the small size of the plants and that low yields with late plantings might be related to the short growing seasons. None of the reports from Florida have investigated these relationships. There have also been no reports on the optimum time of planting for 'Festival' in Florida, though it is a popular cultivar in this area. In the second set of experiments, plants were obtained from nurseries at Stanthorpe in southern Queensland and at Toolangi in Victoria and at Kempton in Tasmania. Stanthorpe is a warm-growing environment, and the other two southern sites are cool-growing environments. The stock from each nursery was classified as small plants with crowns smaller than $10 \mathrm{~mm}$ in diameter and large plants with crowns larger than $10 \mathrm{~mm}$ in diameter.

\section{Materials and methods}

Time of Planting. In year 1 , bare-rooted plants of the strawberry cultivar Festival from Stanthorpe in southern Queensland (lat. 28.6 $\mathrm{S}$, long. $152.0^{\circ} \mathrm{E}$, elevation $\left.872 \mathrm{~m}\right)$ were planted at Nambour (lat. 26.6 $\mathrm{S}$, long. $152.9^{\circ} \mathrm{E}$, elevation $29 \mathrm{~m}$ ) on 5 Mar., 27 Mar., 3 Apr., 17 Apr., or 2 May 2007. The strawberry plants were grown as commercial crops as described by Vock (1997) and Menzel and Toldi (2010). The new stolons produced by the plants after planting from May to July were removed manually every week.

The diameter of the crown, the number of leaves/plant, and plant dry weight were recorded from a sample of plants ( $n=40$ plants per treatment) at planting. Day 1 was the date of the first planting. We also collected data on the number of leaves/plant, leaf area/ plant, and plant dry weight (leaves, crowns, roots, flowers, immature fruit, and mature fruit) about every 3 weeks in the field up until 9 Oct. (Day 219). Mature fruit were classified as those that were at least three-quarters colored. The weights of the new stolons were not included in the weights of the plants. Fruit were harvested every week for an assessment of yield (fresh weight) and fruit fresh weight up until 9 Oct. Average seasonal fruit fresh weight is the long-term average value of fruit fresh weight in a treatment pooled across all harvests.

There were two sections in each block, one for recording plant growth every 3 weeks and an adjacent one for recording yield every week. For the growth data, the experiment was laid out in a split-plot design, with the different times of planting forming the main plots and the different harvest dates forming the split plots. There were four blocks and two plants harvested each time from each block $(n=$ eight plants per treatment). Previous research has shown that a sample of two plants per block was sufficient to obtain significant differences among treatments in this environment, especially with sampling every 3 weeks over the growing season (Menzel and Toldi, 2010). For instance, in the present experiments, the plots were sampled up to nine or ten times over the season for an estimate of plant growth. Butler et al. (2002) used a similar approach to study the effect of different sources and plant types on the growth of strawberry plants in North Carolina. Data on plant growth were collected from four plants per treatment (single plants from each of four replications) with six or seven harvests each year.

For the yield and fruit fresh weight data, the experiment was laid out in a randomized block design, with the fruit harvested each week from the same 20 plants in each plot $(n=80$ plants per treatment). Growth data for the harvests from Day 72 were analyzed by split-plot analysis of variance (ANOVA; five planting dates $\times$ seven harvests) using GenStat (version 11; VSN International, Hemel Hempstead, UK). This analysis included data only up to 18 Sept. (Day 198), after which average total plant dry weight declined. Data on yield and average seasonal fruit fresh weight were analyzed by one-way ANOVA.

The experimental set-up and analyses in year 2 were similar to those described earlier, with the material planted on 5 Mar. (Day 1), 19 Mar., 2 Apr., 16 Apr., or 30 Apr. 2008 ( $n=$ five rather than four blocks per treatment). Data were collected on growth and yield up until 1 Oct. (Day 210). Growth data from Day 63 were analyzed by split-plot ANOVA (five planting dates $\times$ seven harvests). This analysis included data only up to 10 Sept. (Day 189), after which average total plant dry weight declined. In year 3, the experimental set-up was similar to that used in year 2 , with the material planted on 2 Mar. (Day 1), 16 Mar., 2 Apr., 14 Apr., or 28 Apr. 2009. Data were collected on growth up until 28 Sept. (Day 212) and yield up until 6 Oct. (Day 220).

The gross returns from the different treatments were compared using similar analyses as those used to compare yields. The yields (grams per plant) from each treatment for each month from June to October were multiplied by the average price received for strawberry in the Brisbane Markets from 2003 to 2006 to give the gross returns for each treatment. The average price for fruit received in June, July, August, September, and October used in this analysis was (in Australian dollars) A $\$ 2.28$, A $\$ 1.82$, $\mathrm{A} \$ 1.45, \mathrm{~A} \$ 1.13$, and $\mathrm{A} \$ 1.61$ per $250 \mathrm{-g}$ basket, respectively.

The relationship between average vegetative plant dry weight (leaves, crowns, and roots) and the length of the growing season in the different treatments pooled across the 3 years was assessed by regression analysis. A similar analysis was conducted to determine the relationship between yield and plant growth across the different planting times. The graphics software SigmaPlot (version 11; Systat, Chicago, IL) was used to analyze these data.

Plant Size AND NURSeryGROWING ENVIRONMENT. In year 1 , plants of 'Festival' were obtained from Stanthorpe in southern Queensland or from Kempton in Tasmania (lat. $42.4^{\circ} \mathrm{S}$, long. $147.0^{\circ} \mathrm{E}$, elevation 352 $\mathrm{m})$ and planted at Nambour on 17 Apr. 2007 (Day 1). The average daily mean temperature between January and April during plant development is $13.7^{\circ} \mathrm{C}$ at Kempton (a cool-growing area) compared with $18.7^{\circ} \mathrm{C}$ at Stanthorpe 
(a warm-growing area). The stock from each nursery was divided into small plants with crown diameters from 6 to $10 \mathrm{~mm}$ and large plants with crown diameters from 10 to $17 \mathrm{~mm}$. Data were collected on growth and yield as described earlier up until 2 Oct. (Day 169).

There were two sections in each block, one for recording plant growth every 3 weeks and an adjacent one for recording yield every week. For the growth data, the experiment was laid out in a split-split plot design, with sources in the main plots, plant types in the subplots, and harvest dates in the split-split plots. There were four blocks and two plants harvested each time from each block ( $n=$ eight plants per treatment). For the yield data, the experiment was laid out in a split-plot design, with sources in the main plots, plant types in the split plot, with the fruit harvested each week from the same 20 plants in each plot $(n=80$ plants per treatment). The growth data were analyzed by split-split plot ANOVA (two sources $\times$ two plant types $\times$ eight harvests). Data on yield and average seasonal fruit fresh weight were analyzed by split-plot ANOVA (two sources $\times$ two plant types).

Table 1. The effect of time of digging on the initial growth of the 'Festival' strawberry plants from the time of planting experiments at Nambour, Australia, from 2007 to 2009.

\begin{tabular}{|c|c|c|c|c|c|c|}
\hline \multirow{2}{*}{$\begin{array}{l}\text { Time of } \\
\text { digging }\end{array}$} & \multirow{2}{*}{$\begin{array}{l}\text { Diam of the } \\
\text { crown } \\
(\mathrm{mm})^{\mathrm{z}}\end{array}$} & \multirow{2}{*}{$\begin{array}{c}\text { Leaves } \\
\text { (no. } / \text { plant })^{\mathrm{z}}\end{array}$} & \multicolumn{4}{|c|}{ Dry wt $(g / \text { plant })^{z}$} \\
\hline & & & Leaves & Crown & Roots & Plant \\
\hline Early March & 8.4 & 3.6 & 1.9 & 0.3 & 0.3 & 2.5 \\
\hline Mid-March & 8.9 & 3.9 & 2.1 & 0.5 & 0.6 & 3.2 \\
\hline Late March/early April & 9.4 & 3.7 & 2.1 & 0.5 & 0.8 & 3.4 \\
\hline Mid-April & 9.8 & 4.1 & 2.0 & 0.6 & 1.0 & 3.6 \\
\hline Late April/early May & 10.3 & 4.2 & 2.0 & 0.7 & 1.0 & 3.7 \\
\hline Maximum $\mathrm{SE}^{\mathrm{y}}$ & 0.6 & 0.6 & 0.3 & 0.1 & 0.3 & 0.6 \\
\hline
\end{tabular}

${ }^{z}$ Data are the means from 3 years, with 40 plants per treatment each year; $1 \mathrm{~mm}=0.0394 \mathrm{inch}, \mathrm{l} \mathrm{g}=0.0353 \mathrm{oz}$. ${ }^{y}$ Maximum SE is from the SEs calculated with the means presented in a column.

Table 2. The effect of time of planting on average leaf production in 'Festival' strawberry plants during the season at Nambour, Australia, from 2007 to 2009.

\begin{tabular}{lcccc}
\hline $\begin{array}{l}\text { Time of } \\
\text { planting }\end{array}$ & $\begin{array}{c}\text { Leaves } \\
(\text { no./plant })^{\mathbf{z}}\end{array}$ & $\begin{array}{c}\text { Leaf area } \\
\left(\mathbf{c m}^{2} / \text { plant }\right)^{\mathbf{z}}\end{array}$ & $\begin{array}{c}\text { Specific leaf } \\
\text { area }\left(\mathbf{c m}^{2} \cdot \mathbf{g}^{-1}\right. \\
\text { dry } \mathbf{~ w t})^{\mathbf{z}}\end{array}$ & $\begin{array}{c}\text { Single leaf } \\
\text { area }\left(\mathbf{c m}^{2}\right)^{\mathbf{z}}\end{array}$ \\
\hline Early March & 18.7 & 1366 & 123 & 80 \\
Mid-March & 19.1 & 1396 & 127 & 79 \\
Late March/early April & 17.4 & 1298 & 126 & 80 \\
Mid-April & 14.8 & 1010 & 122 & 67 \\
Late April/early May & 13.1 & 855 & 121 & 64 \\
Maximum SE $^{\mathrm{y}}$ & 3.0 & 182 & 3 & 7
\end{tabular}

${ }^{2}$ Data are the means from 3 years, with 28 replicates pooled across seven sampling dates in 2007; 35 replicates pooled across seven sampling dates in 2008; and 40 replicates pooled across eight sampling dates in $2009 ; 1 \mathrm{~cm}^{2}=$ 0.1550 inch $^{2}, 1 \mathrm{~cm}^{2} \cdot \mathrm{g}^{-1}=4.3942 \mathrm{inch}^{2} / \mathrm{oz}, \mathrm{l} \mathrm{g}=0.0353 \mathrm{oz}$.

${ }^{y}$ Maximum SE is from the SES calculated with the means presented in a column.
The set-up and analyses in year 2 were as described earlier, apart from the inclusion of plants from Toolangi in Victoria (lat. $37.6^{\circ} \mathrm{S}$, long. $145.5^{\circ} \mathrm{E}$, elevation $620 \mathrm{~m}$ ). The average daily mean temperature in this area between January and April during plant development is $15.6^{\circ} \mathrm{C}$ (a cool-growing environment). The small and large stocks from each of the three nurseries were planted on 9 Apr. 2008 (Day 1). Data on growth and yield were collected up until 24 Sept. (Day 178) and until 8 Oct. (Day 192), respectively. The experimental layout was as described earlier, except that there were three sources of plants rather than two. The set-up in year 3 was similar to that in year 2, with plants from Stanthorpe, Toolangi, or Kempton. The stock was planted on 7 Apr. 2009 (Day 1), with data collected on growth up until 21 Sept. (Day 168) and yield up until 6 Oct. (Day 183). The gross returns from the different treatments were compared as described earlier. The relationship between yield and plant growth in the different treatments pooled across the 3 years was assessed by regression analysis by using the graphics software SigmaPlot (version 11). These data were pooled with the data from the time of planting experiment.

\section{Results}

The responses over the 3 years were generally similar in the two sets of experiments. Hence, the data from the 3 years were pooled for each set of experiments. These general means (except for yield and returns) are presented with a maximum SE. Maximum $S E$ is obtained from the SES calculated with the means for each individual treatment.

In the ANOVA to examine the effect of planting date on growth,

Table 3. The effect of time of planting on the average production and distribution of dry matter [within brackets] in 'Festival' strawberry plants during the season at Nambour, Australia, from 2007 to 2009.

\begin{tabular}{|c|c|c|c|c|c|c|}
\hline \multirow[b]{2}{*}{ Time of planting } & \multicolumn{6}{|c|}{ Dry wt (g/plant) or [dry wt distribution $(\%)]^{\mathrm{z}}$} \\
\hline & Leaves & Crowns & Roots & $\begin{array}{c}\text { Flowers and } \\
\text { immature fruit }\end{array}$ & $\begin{array}{c}\text { Flowers and } \\
\text { all fruit }\end{array}$ & Plant \\
\hline Mid-March & $11.4[44.1]$ & $4.3[15.8]$ & $2.6[9.7]$ & 7.1 & $9.9[30.4]$ & 28.2 \\
\hline Late March/early April & $10.8[44.8]$ & $3.8[15.6]$ & $2.6[11.6]$ & 5.9 & $8.6[28.0]$ & 25.8 \\
\hline Mid-April & $8.4[43.7]$ & $2.9[15.4]$ & $2.2[14.3]$ & 4.7 & $6.9[26.6]$ & 20.4 \\
\hline
\end{tabular}

${ }^{2}$ Data are the means from 3 years, with 28 replicates pooled across seven sampling dates in $2007 ; 35$ replicates pooled across seven sampling dates in 2008 ; and 40 replicates pooled across eight sampling dates in $2009 ; 1 \mathrm{~g}=0.0353 \mathrm{~g}$.

${ }^{y}$ Maximum SE is from the SES calculated with the means presented in a column. 
yield, and returns, planting time had a significant effect on most of the parameters measured each year, with most ANOVAs giving $P=0.001$, a few with $P=0.05$ to 0.002 , and a few with $P>$ 0.05 or not significant (root dry weight and proportion of dry weight in the crowns in 2008 and specific leaf area and single leaf area in 2009).

In the ANOVA to examine the effect of nursery-growing area on growth, yield, and returns, nurserygrowing area had a mixed effect on performance each year, with the two nurseries in southern Australia not clearly better than the nursery in Queensland. In the ANOVA to examine the effect of plant type on growth, yield, and returns, plant type had a significant effect on most of the parameters measured each year, with most ANOVAs giving $P=0.001$, a few with $P=0.014$ to 0.002 , and a few with $P>0.05$ or not significant (average fruit fresh weight and the proportion of dry weight in the leaves in 2007; single leaf area and the proportion of dry weight in the leaves in 2008; and average fruit fresh weight, single leaf area, and the proportion of dry weight in the leaves in 2009).

Time of Planting. There was a gradual increase in the diameter of the crowns as digging on the nursery farm was delayed, but no clear trend was observed in leaf production (Table 1 ). Plant dry weight also increased as digging was delayed, mainly because of higher crown and root weights.

Yield was greatest in the plants planted in mid-March $[1013 \pm 86 \mathrm{~g} /$ plant $( \pm \mathrm{SE})]$, followed by those planted in late March/early April $(765 \pm 38 \mathrm{~g} /$ plant $)$ or in early March $(711 \pm 183 \mathrm{~g} /$ plant) and then those planted in midApril $(671 \pm 37 \mathrm{~g} /$ plant $)$ or in late April/early May $(542 \pm 16 \mathrm{~g} /$ plant $)$. Average seasonal fruit fresh weight was greatest in the plants planted in midMarch $(17.0 \mathrm{~g})$, with smaller fruit in the plants planted at the other times $(15.5$ to $15.7 \mathrm{~g})$ ( maximum $\mathrm{SE}=1.6)$. The profitability of the different treatments reflected yield. Return was greatest in the stock planted in midMarch (A\$6.24 \pm A \$0.5l/plant), followed by those planted in late March/ early April (A \$4.56 \pm A $\$ 0.18 /$ plant $)$ or in early March (A\$4.25 \pm A $\$ 1.17 /$ plant) and then those planted in mid-April (A\$3.94 \pm A $\$ 0.24 /$ plant $)$ or in late April/early May (A\$3.15 \pm A $\$ 0.08 /$ plant).
Average leaf production and leaf area/plant were higher in the plots planted by early April compared with those planted after mid-April (Table $2)$. Less total leaf area/plant was due to slightly smaller leaves in the plants planted after mid-April, whereas there was no clear trend in the thickness of the leaves across the different treatments (Table 2).

Total plant dry weight was higher in the plants planted by early April compared with values in the plants planted after mid-April (Table 3). These responses were associated with higher leaf, crown, and root weights in the first three plantings. By contrast, the highest flower and fruit dry weights occurred in the plants planted in midMarch, with lower values in the other treatments.

The stock planted in mid-March or in late March/early April had greater proportions of plant dry weight allocated to the flowers and the fruit than the stock planted at the other times (Table 3). These responses were associated with an increased allocation to the leaves in the earlier planting and an increased allocation to the roots in the later plantings. Across the five different planting times, $27 \%$ of plant dry matter was distributed to the flowers and fruit (average over the season), $45 \%$ to the leaves, $16 \%$ to the crowns, and $12 \%$ to the roots.

The changes in growth over the 3 years were similar. Hence, only the changes in the third year are presented. Within that experiment, only the changes for the plantings on 2 Mar., 16 Mar., and 28 Apr. are shown to indicate the range in the responses (Figs. 1-3).

The changes in leaf production over time were linear in the plots planted on 2 Mar. and 28 Apr. and sigmoidal in the plots planted on 16 Mar. (Fig. 1). By contrast, the changes in leaf area development were all sigmoidal. This indicates that the stock planted in early March or in late April was still initiating new leaves at the end of the experiment, whereas maximum leaf area development occurred earlier in all three planting times. The stock

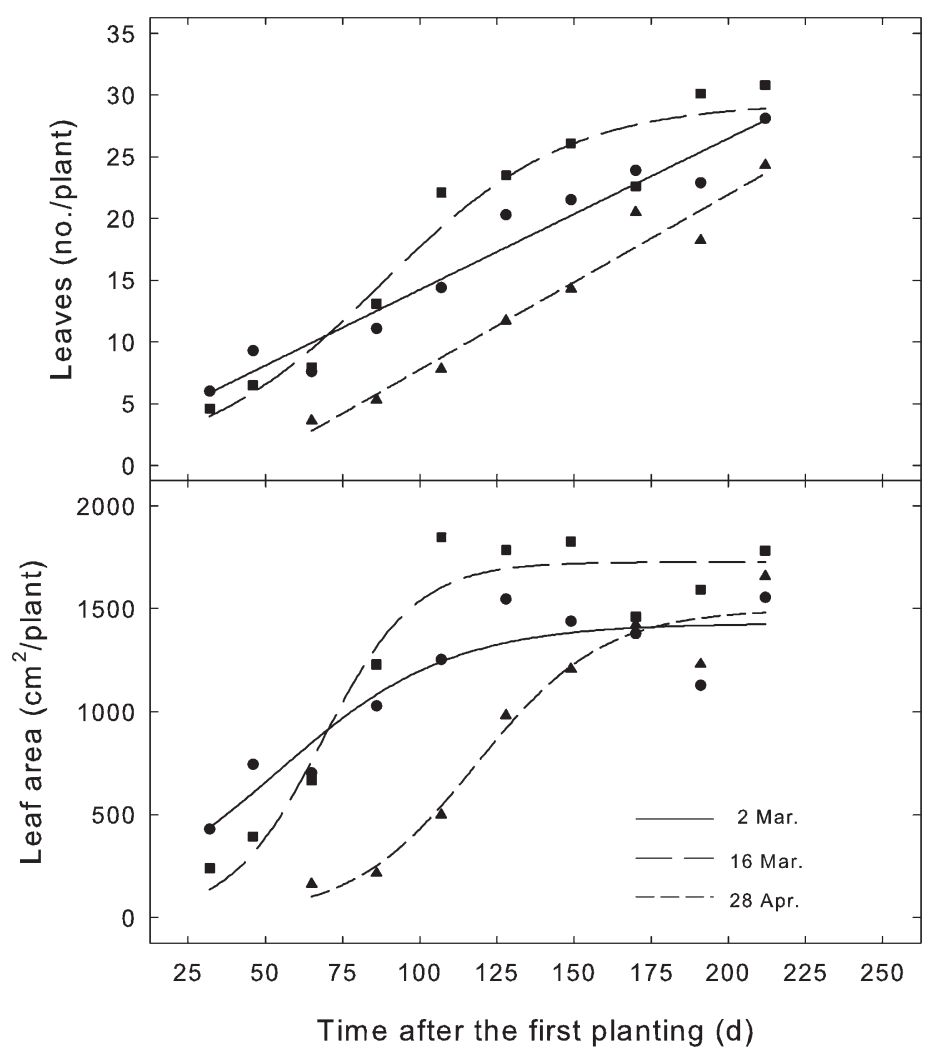

Fig. 1. The effect of time of planting on the changes in leaf production and leaf area expansion in 'Festival' strawberry plants grown at Nambour, Australia, in 2009. Data are the means of five replicates per treatment $(N=8$ or 10). Only the changes in three out of the five planting times are shown. Circles = 2 Mar., squares = 16 Mar., and triangles $=28 \mathrm{Apr}$. $1 \mathrm{~cm}^{2}=0.1550 \mathrm{inch}^{2}$. 


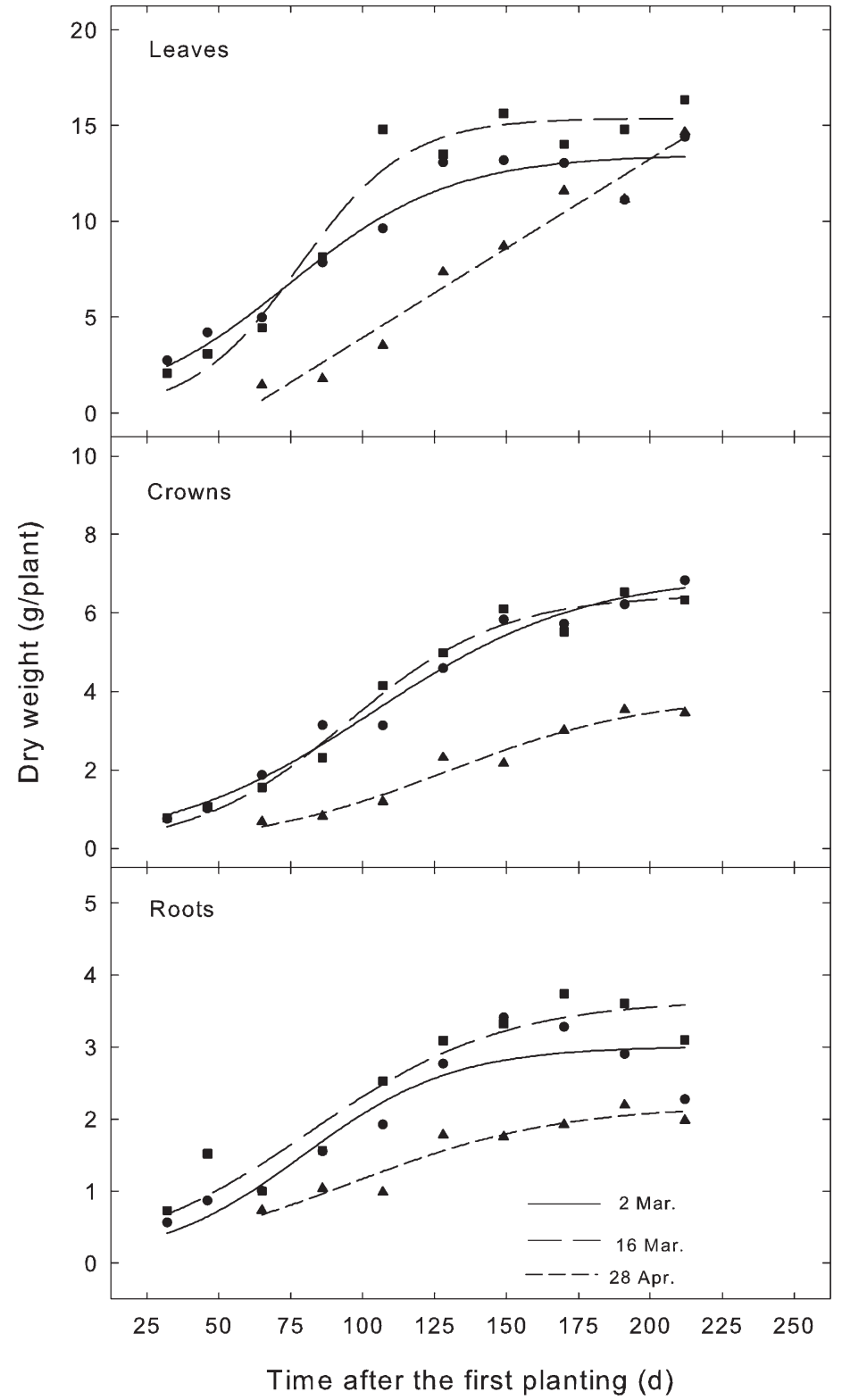

Fig. 2. The effect of time of planting on the changes in dry weight of the leaves, crowns, and roots in 'Festival' strawberry plants grown at Nambour, Australia, in 2009. Data are the means of five replicates per treatment $(N=8$ or 10). Only the changes in three out of the five planting times are shown. Circles $=2$ Mar., squares $=$ 16 Mar., and triangles = 28 Apr.; $1 \mathrm{~g}=0.0353 \mathrm{oz}$.

planted on 2 and 16 Mar. produced more leaves by the end of the season than the stock planted on 28 Apr. Final leaf area expansion was greatest in the stock planted on 16 Mar.

The changes in plant dry weight over time were all sigmoidal, except for the change in leaf dry weight in the stock planted on 28 Apr., which was linear (Figs. 2 and 3). Maximum leaf weight was similar in the three plantings, maximum crown weight was greater in the first and second plantings, and maximum root weight was greatest in the second planting. Maximum total plant weight and reproductive weight were greatest in the second planting.

The proportion of plant dry matter distributed to the leaves and roots decreased as plant dry weight increased (Fig. 4). At the end of the experiment across all planting times, $39 \%$ of plant dry weight was allocated to the flowers and fruit, $38 \%$ to the leaves, $15 \%$ to the crowns, and $8 \%$ to the roots.

There was a strong relationship between the plant vegetative dry weight (leaves, crowns, and roots) and the length of the growing season in the different treatments (Fig. 5). Typically, plant growth increased by $\approx 50 \%$ as the production season increased from 144 to $200 \mathrm{~d}$. There was a strong relationship between yield and the average vegetative plant dry weight during the season for the last four planting times (Fig. 6). The plots planted in early March had slightly higher rates of vegetative plant growth than the plots planted in mid-March, but had lower yields. This treatment was excluded from the analysis. The data from this experiment were combined with the data from the source experiment to show the general relationship between yield and vegetative plant growth.

Plant SIZE AND NURSERY-Growing ENVIRONMENT. The data have been pooled as there were only small differences in the size and weights of plants from the different nurseries. The data have also been pooled as the differences between the small and the large plants were similar across the three nurseries.

The large plants had wider crowns than the small plants at planting, slightly more leaves, and higher dry weights (Table 4). The large plants were about three times the weight of the small plants. By contrast, there were only small differences in growth among the stock from the different nurseries.

The large stock yielded $17 \%$ more than the small stock $(751 \pm 27$ vs. $642 \pm$ $52 \mathrm{~g} /$ plant). In contrast, the plants from Stanthorpe $(695 \pm 18 \mathrm{~g} /$ plant $)$, Toolangi $(710 \pm 47 \mathrm{~g} /$ plant $)$, and Kempton $(701 \pm 71 \mathrm{~g} /$ plant $)$ had similar productivity. There were only small differences in average seasonal fruit fresh weight across the different treatments. Average values were 17.5 $\mathrm{g}$ in the small plants and $17.0 \mathrm{~g}$ in the large plants (maximum $\mathrm{SE}=1.0$ ). Similarly, average values were 16.7 $\mathrm{g}$ in the plants from Stanthorpe, 17.1 $\mathrm{g}$ in the plants from Toolangi, and $17.6 \mathrm{~g}$ in the plants from Kempton (maximum $\mathrm{SE}=1.8)$. The profitability of the different stock reflected their yield. The large plants returned $\mathrm{A} \$ 4.51 \pm \mathrm{A} \$ 0.18 /$ plant, but the small plants returned A\$3.71 $\pm \mathrm{A} \$ 0.31 /$ plant. By contrast, the net profits of the material from the three nurseries were similar $(\mathrm{A} \$ 4.06 \pm \mathrm{A} \$ 0.10$, $\mathrm{A} \$ 4.24 \pm \mathrm{A} \$ 0.12$, and $\mathrm{A} \$ 4.17 \pm$ $\mathrm{A} \$ 0.50)$. 


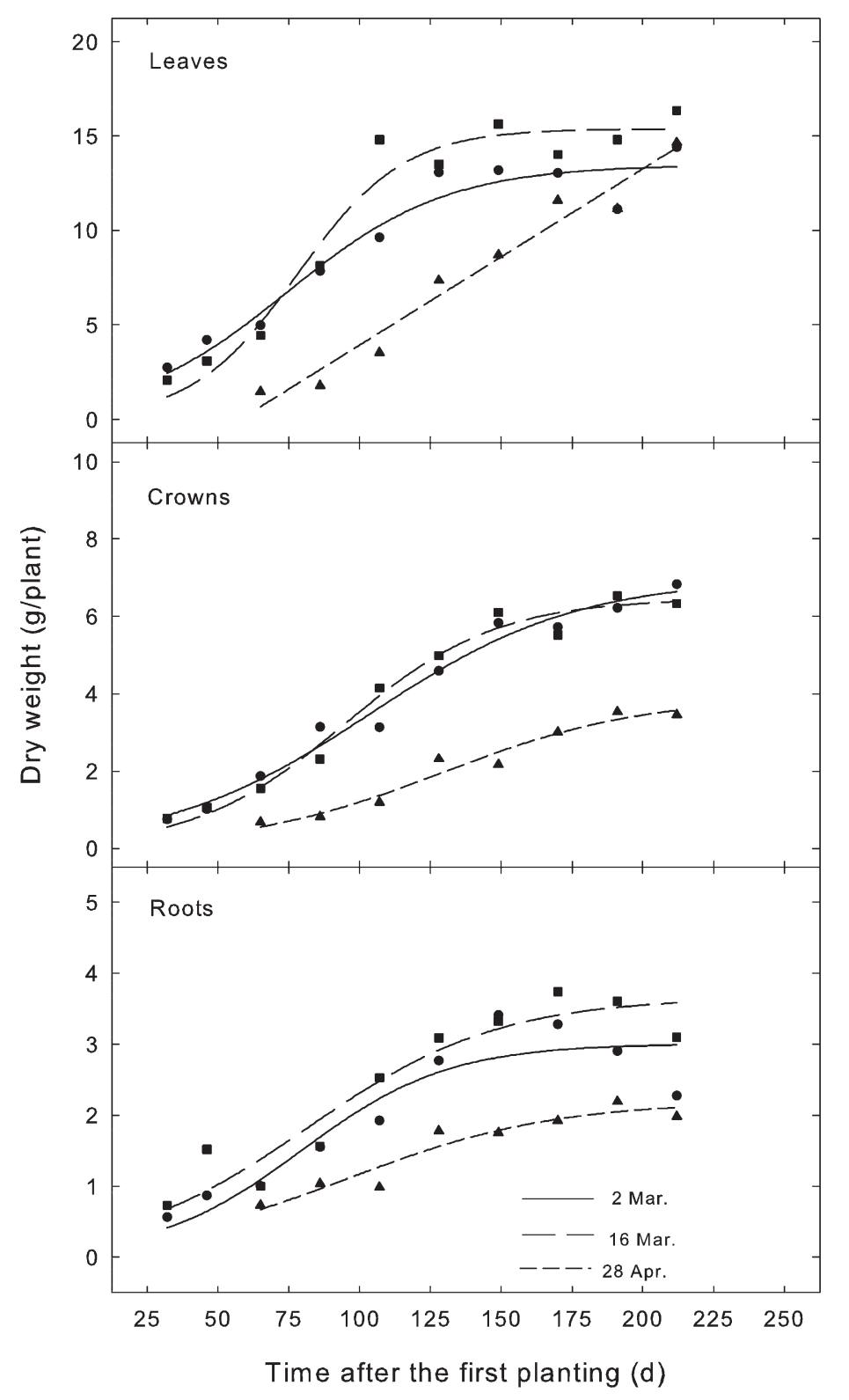

Fig. 3. The effect of time of planting on the changes in dry weight of the flowers, fruit, and whole plants in 'Festival' strawberry plants grown at Nambour, Australia, in 2009. Data are the means of five replicates per treatment $(N=8$ or 10). Only the changes in three out of the five planting times are shown. Circles $=2$ Mar., squares = 16 Mar., and triangles $=28$ Apr.; $1 \mathrm{~g}=0.0353 \mathrm{oz}$.

The large plants had more leaves and leaf area/plant during the growing season than the small plants (Table 5 ). In contrast, there were only small differences in the plants from the three nurseries. Differences in the size and thickness of the leaves were small. The responses of the treatments were consistent over time, and so only the mean values across the season are shown. This also occurred with the other aspects of growth measured over time.

All components of dry matter production were greater in the large roots decreased as plant dry weight increased (data not presented). At the end of the experiment across all the treatments, about $30 \%$ of plant dry weight was allocated to the flowers and fruit, $40 \%$ to the leaves, $20 \%$ to the crowns, and $10 \%$ to the roots.

There was a relationship between yield and vegetative plant dry weight (leaves, crowns, and roots) in the different treatments (small plants, large plants, and plants from Stanthorpe, Toolangi, or Kempton) (Fig. 6). Productivity increased as plant dry weight increased, indicating the dependence of fruit production on vegetative growth in this environment. The data from this experiment were combined with the data from the time of planting experiment to show the general relationship between yield and vegetative plant growth.

\section{Discussion}

Time of planting and plant size had strong effects on the growth and productivity of 'Festival' grown in a subtropical environment. In contrast, the effect of nursery-growing environment was small. Overall yields and returns were best when the material was planted in mid-March. Lower yields with an early planting were associated with the small size of the stock, whereas lower yields with later plantings were associated with the shorter growing seasons. In the plant size experiments, the large stock out-yielded the small stock.

The EFFeCt of time of PLANTING ON PRODUCTIVITY. The best yields occurred when the plants were planted in mid-March, with $24 \%$ to $33 \%$ lower yields when the plants were planted in early March, late March/early April, or mid-April. Yields were much lower when the plants were planted in late April/early May, with a $47 \%$ reduction compared with the yield achieved with the optimum planting time.

Several studies have examined the effect of planting date on the productivity of strawberry fields in Florida, with the bare-rooted plants obtained from local nurseries (Albregts and Chandler, 1994; Albregts and Howard, 1974, 1977, 1980; Chandler et al., 1991; Locascio, 1972). Two investigations have examined the performance of containerized plants or plants from interstate nurseries in North Carolina or Canada (Durner 


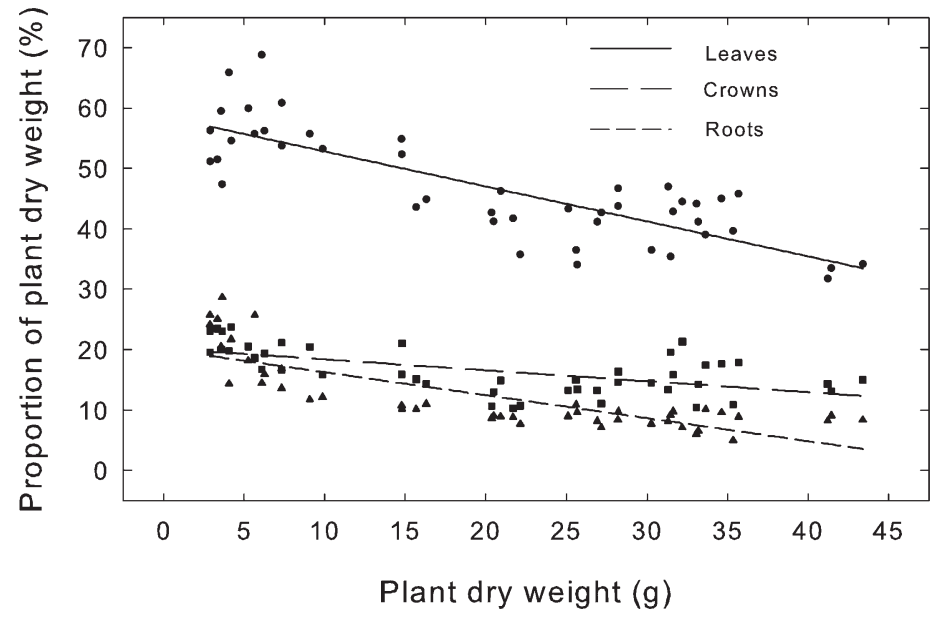

Fig. 4. The relationship between the distribution of plant dry matter production and plant dry weight (DW) in 'Festival' strawberry plants grown at Nambour, Australia, during the time of planting experiment in 2009. Data are the means of five replicates per treatment, with all the different times of planting $(N=40)$. Circles $=$ leaves, squares $=$ crowns, and triangles $=$ roots; percent $\mathrm{DW}_{\text {Leaves }}=\mathbf{5 8 . 6}-$ $0.58 \mathrm{DW}_{\text {Plant }}\left(R^{2}=0.66\right)$; percent $\mathrm{DW}_{\text {Crowns }}=20.2-0.18 \mathrm{DW}_{\text {Plant }}\left(R^{2}=0.34\right)$; and percent $\mathrm{DW}_{\text {Roots }}=20.0-0.38 \mathrm{DW}_{\text {Plant }}\left(R^{2}=0.62\right) ; 1 \mathrm{~g}=0.0353 \mathrm{oz}$.

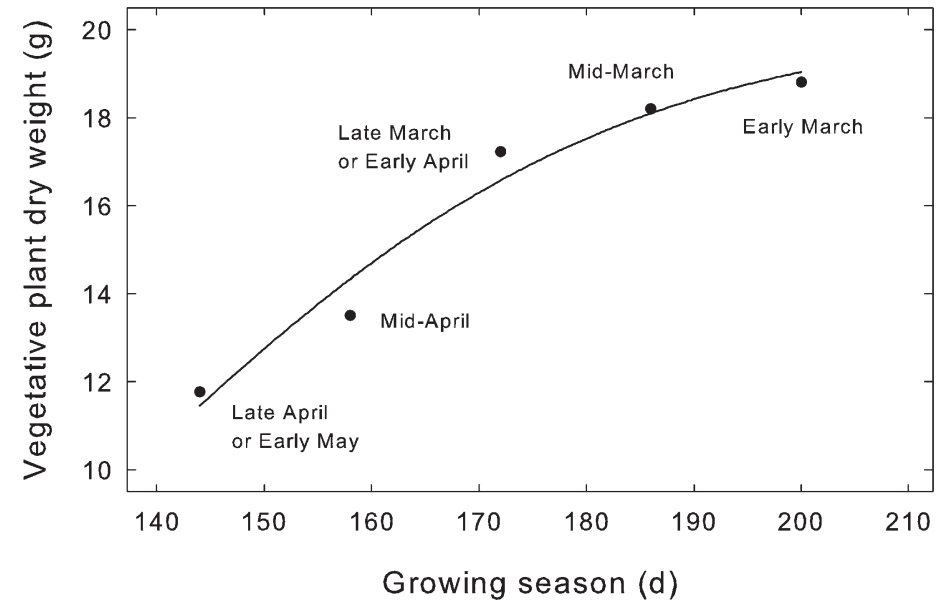

Fig. 5. The relationship between average seasonal vegetative plant dry weight (leaves, crowns, and roots) and the length of the growing season in 'Festival' strawberry plants grown at Nambour, Australia, during the time of planting experiments in 2007,2008 , and 2009. Data are the means of 12 or 15 replicates pooled across the 3 years $(N=5)$; dry weight $=20.3 /\{1+\exp [-($ day -138.1$) /$ $22.6]\}\left(R^{2}=0.93\right) ; 1 \mathrm{~g}=0.0353 \mathrm{oz}$.

et al., 1986; Duval et al., 2005). An analysis of these reports indicates that planting date affected yield in nearly all cases. Cropping was generally best when the stock was planted in early to mid-October, which is equivalent to the stock planted in early to mid-April in southeastern Queensland.

There was a gradual increase in the size of the crowns and roots as digging was delayed. Average plant dry weight was $2.5 \pm 0.3 \mathrm{~g} /$ plant in the first planting and $3.2 \pm 0.2 \mathrm{~g} /$ plant in the second planting, with higher productivity in the latter. By contrast, there was no increase in productivity in the later plantings as plant dry weight increased up to a maximum of $3.7 \pm 0.3 \mathrm{~g} /$ plant. These results suggest that the first set of stock was too small for optimum production, whereas the growing season was too short for the later sets of stock to produce reasonable crops. None of the reports in Florida indicate if lower yields with early plantings were due to the plants being small. Lower yields with later plantings were presumably due to the short growing seasons.

The EFFeCt OF PLANT SIZE ON PRODUCTIVITY. Over the 3 years, the large plants had higher yields than the small plants in the second set of experiments. The difference in productivity between the two groups of stock was $17 \%$. This difference in productivity was related to differences in dry matter production in the nursery material and differences in plant growth during the season. The large plants were about three times the weight of the small plants at planting and were about 1.5 times the weight of the small plants during the growing season.

The two categories of plants were based on the size of the crowns, with the small plants having crown diameters from 6 to $10 \mathrm{~mm}$ and the large plants having crown diameters from 10 to $17 \mathrm{~mm}$. Surveys of 'Festival' plants from the three nurseries showed that about $10 \%$ of transplants had crowns smaller than $8 \mathrm{~mm}$ and $40 \%$ had crowns smaller than $10 \mathrm{~mm}$ (C.M. Menzel, unpublished data). It is apparent that small differences in diameter of the crown can translate into large differences in productivity.

Two studies in Florida have assessed the importance of the initial size of the nursery material on subsequent growth and yield, using both bare-rooted and containerized plants (Bish et al., 1997, 2002). The large stock had higher yields than the small stock in only two out of eight cases. Johnson et al. (2005) conducted similar work in Louisiana using 'Chandler' and 'Camarosa', with the bare-rooted plants with leaves having average crown diameters ranging from 6 to $22 \mathrm{~mm}$ over the 3 years. The authors showed that there were weak relationships between yield and initial size of the crowns in the two cultivars $\left(R^{2}\right.$ of 0.32 and 0.44 ).

The effect of plant size on the productivity of strawberry in Florida appears to vary with the season and growing environment. Large plants do not always produce heavier crops than small plants. It is possible that large plants out-perform small plants only when they have balanced leaf, crown, and root development. Barerooted plants from Stanthorpe, Toolangi, and Kempton had $56 \%$ of their 


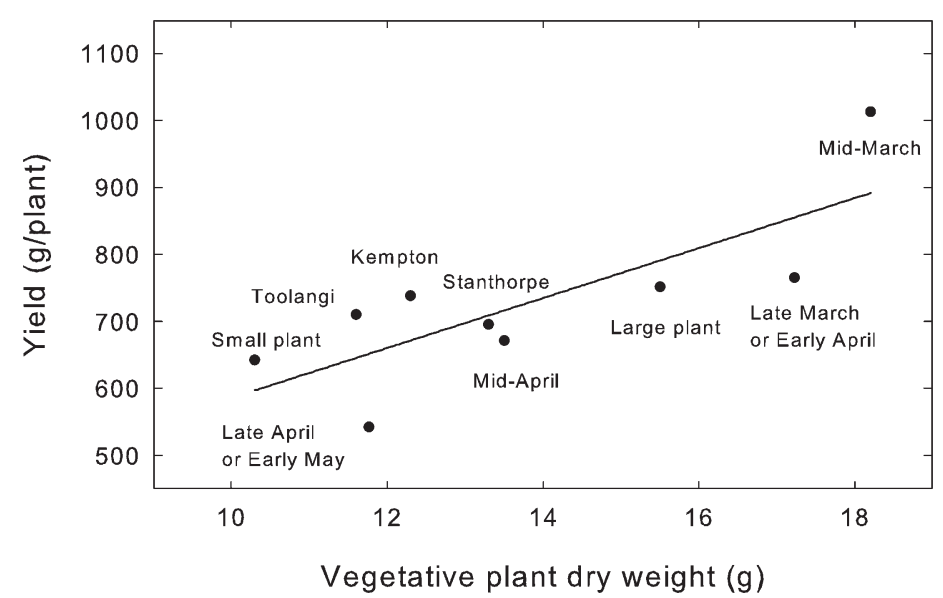

Fig. 6. The relationship between yield and average seasonal vegetative plant dry weight (leaves, crowns, and roots) in 'Festival' strawberry plants grown at Nambour, Australia, during the time of planting and nursery source experiments in 2007,2008 , and 2009. The labels show the individual treatments in the two experiments. The plants in the source experiment came from Stanthorpe in Queensland (a warm-growing area) and from Toolangi in Victoria or Kempton in Tasmania (cool-growing areas). The small plants had crown diameters from 6 to $10 \mathrm{~mm}$ (0.236 to 0.394 inch $)$, and the large plants had crown diameters from 10 to $17 \mathrm{~mm}$ ( 0.394 to 0.670 inch $)$. Data are the means of 8 to 15 replicates pooled across 2 or 3 years. The data for early March in the time of planting experiments are not included in the regression $(N=9)$; yield $=212+37.3 \times$ dry weight $\left(R^{2}=0.57\right)$; $1 \mathrm{~g}=0.0353 \mathrm{oz}$.

Table 4. The variation in the initial growth of the small and large 'Festival' strawberry plants from Stanthorpe in Queensland (a warm-growing area) and from Toolangi in Victoria and Kempton in Tasmania (cool-growing areas) in Australia from 2007 to 2009.

\begin{tabular}{|c|c|c|c|c|c|c|}
\hline \multirow{2}{*}{$\begin{array}{l}\text { Source of nursery } \\
\text { stock or plant type }\end{array}$} & \multirow{2}{*}{$\begin{array}{l}\text { Diam of the } \\
\text { crown } \\
(\mathrm{mm})^{\mathrm{z}}\end{array}$} & \multirow{2}{*}{$\begin{array}{c}\text { Leaves } \\
\text { (no./plant })^{\mathrm{z}}\end{array}$} & \multicolumn{4}{|c|}{ Dry wt $(\mathrm{g} / \text { plant })^{\mathrm{z}}$} \\
\hline & & & Leaves & Crown & Roots & Plant \\
\hline Small plant ${ }^{\mathrm{y}}$ & 7.6 & 2.7 & 0.9 & 0.3 & 0.4 & 1.6 \\
\hline Large plant $\mathrm{y}^{\mathrm{y}}$ & 12.6 & 3.8 & 2.7 & 0.9 & 1.1 & 4.7 \\
\hline Maximum $\mathrm{SE}^{\mathrm{x}}$ & 0.4 & 0.2 & 0.1 & 0.1 & 0.2 & 0.2 \\
\hline $\begin{array}{l}\text { Plant from Stanthorpe, } \\
\text { Queensland }\end{array}$ & 9.7 & 3.5 & 2.0 & 0.6 & 0.9 & 3.5 \\
\hline $\begin{array}{l}\text { Plant from Toolangi, } \\
\text { Victoria }\end{array}$ & 9.8 & 3.4 & 1.7 & 0.6 & 0.8 & 3.1 \\
\hline $\begin{array}{l}\text { Plant from Kempton, } \\
\text { Tasmania }\end{array}$ & 11.1 & 3.0 & 1.8 & 0.7 & 0.6 & 3.1 \\
\hline$\underline{\text { Maximum SE }}$ & 0.5 & 0.4 & 0.3 & 0.1 & 0.3 & 0.4 \\
\hline
\end{tabular}

${ }^{z}$ Data are the means pooled over 2 or 3 years, with 20 or 40 samples per treatment each year. The plants were dug in early or mid-April each year. The differences between the small and the large bare-rooted plants were similar in the three growing areas; $1 \mathrm{~mm}=0.0394$ inch, $1 \mathrm{~g}=0.0353 \mathrm{oz}$.

The small plants had crown diameters from 6 to $10 \mathrm{~mm}(0.236$ to 0.394 inch), and the large plants had crown diameters from 10 to $17 \mathrm{~mm}$ (0.394 to 0.670 inch).

${ }^{\mathrm{x}}$ Maximum SE is from the SES calculated with the means presented in a column.

non-structural carbohydrates stored in the leaves, $18 \%$ in the crowns, and $26 \%$ in the roots (C.M. Menzel, unpublished data). These data indicate the importance of reserves stored in the leaves for the growth of the new plants in southeastern Queensland. The plants also need a sound root system to reduce the impact of water deficits on plant growth in the first 2 weeks after planting under the over-head irrigation (Menzel and Toldi, 2010).

THE EFFECT OF NURSERYGROWING ENVIRONMENT ON PRODUCTIVITY. The bulk of the nursery stock used in Florida comes from the northern United States or Canada (Duval et al., 2005). It is presumed that the cooler conditions in the northern nurseries provide better conditions for the new plants and higher productivity when they are planted (although this is not always the case). There are differences in day length among the different growing areas, which are likely to affect flowering and production in short-day strawberry cultivars (Stewart and Folta, 2010). The northern material also generally has fewer diseases (MacKenzie et al., 2009; Peres et al., 2006). In the present experiments, plants from Queensland were just as productive as plants from Victoria or Tasmania. Conversely in Florida, plants from northern or midlatitude nurseries out-yielded those from southern nurseries in about half the cases.

The Relationship BeTWEen PRODUCTIVITY AND TEMPERATURE IN THE DIFFERENT NURSERY-GROWING ENVIRONMENTS. Average daily temperatures during plant development from January to April are about 3 to $5{ }^{\circ} \mathrm{C}$ lower at Toolangi and Kempton compared with conditions at Stanthorpe. These differences in temperatures are due to differences in daily minimums $\left(10.7,6.5\right.$, and $13.3{ }^{\circ} \mathrm{C}$ ) and maximums $(20.4,20.9$, and $24.2^{\circ} \mathrm{C}$ ).

Several authors have assessed the impact of low temperatures before planting on fruiting in Florida (Albregts and Chandler, 1994; Albregts and Howard 1974, 1977; Bish et al., 1997, 2002; Durner and Poling, 2000; Durner et al., 1986; Locascio, $1972)$. The plants were cooled for 2 to 4 weeks (usually 2 weeks) at various temperatures, including $0.6,2,4.4$, 10,12 , or $15^{\circ} \mathrm{C}$. Temperatures close to freezing were provided by storing the freshly dug plants in cold rooms. Temperatures above freezing were provided by potting up the plants after digging and growing them in phytotrons or glasshouses. When the plants were stored at low temperatures after digging, chilling had a mixed effect or no effect on yield. By contrast, when the plants were potted up and grown at low temperatures, chilling generally resulted in higher yields compared with the performance of plants grown at higher temperatures.

There have been at least two studies that have examined the impact of environmental conditions on the distribution of growth in the new transplants. Kirschbaum et al. (1998) indicated that bare-rooted plants from QC, Canada, had higher leaf dry weights than bare-rooted plants from 
Florida over a single season. Differences in crown and root dry weight between the two groups of plants were small or not significant. Average daily temperatures in September in the month before the plants were dug are 15.0 and $27.2{ }^{\circ} \mathrm{C}$ at the two sites, respectively. Bish et al. (2002) showed that containerized plants grown at $25 / 15{ }^{\circ} \mathrm{C}$ for 2 weeks had a larger root weight than those grown at 35/ $25^{\circ} \mathrm{C}$. Differences in the weights of the leaves and crowns were not significant. These results suggest that differences in productivity of plants from cool- or warm-growing areas probably reflect differences in leaf or root growth. In our experiments, the plants from Toolangi and Kempton were similar to those from Stanthorpe, reflecting similar growing temperatures.

The Relationship BetWeEN YIELD AND DRY MATTER PRODUCTION. There was a strong relationship between the dry matter production and the length of the growing season associated with the different times of planting (Fig. 5). The stock planted in early March produced $50 \%$ more dry matter in the vegetative plant parts than the stock planted in late April or early May. In this analysis, the crowns (a 92\% increase) were more sensitive than the leaves (a 61\% increase) or the roots (a 23\% increase). The time of planting has also been shown to affect plant growth in Florida,

Table 5. The effect of plant size and nursery-production area on average leaf production in 'Festival' strawberry plants at Nambour, Australia, from 2007 to 2009 .

\begin{tabular}{|c|c|c|c|c|}
\hline $\begin{array}{l}\text { Source of nursery } \\
\text { stock or plant type }\end{array}$ & $\begin{array}{c}\text { Leaves } \\
\text { (no./plant })^{\mathrm{z}}\end{array}$ & $\begin{array}{c}\text { Leaf area } \\
\left(\mathrm{cm}^{2} / \text { plant }\right)^{\mathrm{z}}\end{array}$ & $\begin{array}{r}\text { Specific leaf } \\
\text { area }\left(\mathrm{cm}^{2} \cdot \mathrm{g}^{-1}\right. \\
\text { dry } w \mathrm{t})^{\mathrm{z}}\end{array}$ & $\begin{array}{l}\text { Single leaf } \\
\text { area }\left(\mathrm{cm}^{2}\right)^{\mathrm{z}}\end{array}$ \\
\hline Small plant ${ }^{y}$ & 10.9 & 796 & 126 & 72 \\
\hline Large plant ${ }^{y}$ & 15.5 & 1114 & 121 & 73 \\
\hline Maximum $\mathrm{SE}^{\mathrm{x}}$ & 1.4 & 160 & 1 & 6 \\
\hline $\begin{array}{l}\text { Plant from Stanthorpe, } \\
\text { Queensland }\end{array}$ & 14.3 & 984 & 124 & 68 \\
\hline $\begin{array}{l}\text { Plant from Toolangi, } \\
\text { Victoria }\end{array}$ & 11.3 & 843 & 126 & 74 \\
\hline $\begin{array}{l}\text { Plant from Kempton, } \\
\text { Tasmania }\end{array}$ & 12.6 & 908 & 123 & 72 \\
\hline Maximum SE & 1.8 & 192 & 3 & 6 \\
\hline
\end{tabular}

The plants came from Stanthorpe in Queensland (a warm-growing area) and from Toolangi in Victoria and Kempton in Tasmania (cool-growing areas).

${ }^{2}$ Data are the means pooled over 2 or 3 years, with 32 replicates per treatment pooled across eight sampling dates each year. The differences between the small and the large bare-rooted plants were similar in the three growing areas; $\mathrm{l} \mathrm{cm}^{2}=0.1550$ inch $^{2}, \mathrm{l} \mathrm{cm}^{2} \cdot \mathrm{g}^{-1}=4.3942 \mathrm{inch}^{2} / \mathrm{oz}, \mathrm{l} \mathrm{g}=0.0353 \mathrm{oz}$.

y The small plants had crown diameters from 6 to $10 \mathrm{~mm}(0.236$ to 0.394 inch), and the large plants had crown diameters from 10 to $17 \mathrm{~mm}$ (0.394 to 0.670 inch).

${ }^{x}$ Maximum SE is from the SES calculated with the means presented in a column.

although many of the studies only report growth in relative terms (Albregts and Howard, 1974, 1977, 1980; Locascio, 1972). Generally, stock planted in early or mid-October produced larger plants than stock planted later.

There was a strong relationship between yield and average vegetative plant dry weight (leaves, crowns, and roots) during the season in the two sets of experiments (Fig. 6). This analysis showed that the plants produced an extra $37 \mathrm{~g}$ of fruit for each gram of plant dry weight above the minimum weight of $10.3 \mathrm{~g}$. The plants planted in early March in the first set of experiments were excluded from this analysis as they had a slightly higher rate of vegetative growth than the plants planted in mid-March, but lower productivity.

THE DISTRIBUTION OF PLANT DRY MATTER. The allocation of plant dry matter changed over the season as the plants grew. The young plants without fruit allocated about $50 \%$ to $60 \%$ of their dry matter to the leaves and about $20 \%$ to $25 \%$ each to the crowns and roots. In contrast, the mature plants with fruit allocated $40 \%$ of their dry matter to the leaves and about $10 \%$ to the roots. Allocation to the crowns was not strongly affected.

The time of planting affected the distribution of plant dry matter. The stock planted before the time for best yield allocated less dry matter to the flowers and fruit than the stock planted at the optimum time. This response was associated with a greater allocation to the leaves. There was a different response when the stock was planted

Table 6. The effect of plant size and nursery-production area on average dry matter production and distribution [within brackets] in 'Festival' strawberry plants at Nambour, Australia, from 2007 to 2009.

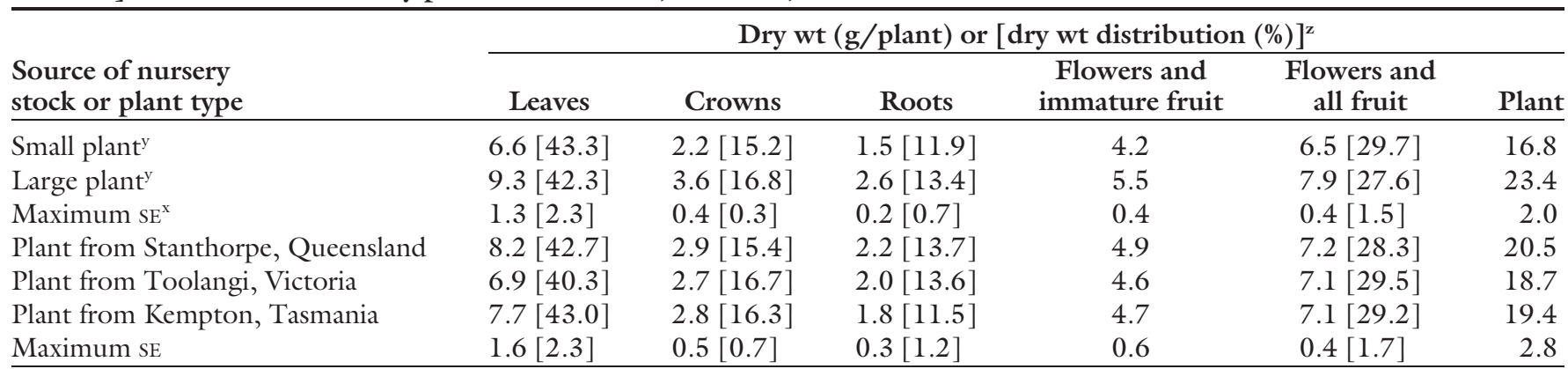

The plants came from Stanthorpe in Queensland (a warm-growing area) and from Toolangi in Victoria and Kempton in Tasmania (cool-growing areas).

${ }^{2}$ Data are the means pooled over 2 or 3 years, with 32 replicates per treatment pooled across eight sampling dates each year. The differences between the small and the large barerooted plants were similar in the three growing areas; $1 \mathrm{~g}=0.0353 \mathrm{oz}$.

y The small plants had crown diameters from 6 to $10 \mathrm{~mm}(0.236$ to 0.394 inch), and the large plants had crown diameters from 10 to $17 \mathrm{~mm}(0.394$ to 0.670 inch).

${ }^{x}$ Maximum $\mathrm{SE}$ from the SEs calculated with the means presented in a column. 
after the optimum time. In these instances, the roots were favored over the reproductive tissues. In the second set of experiments, there were at best only small differences in dry matter distribution across the different sources and plant sizes.

Forney and Breen (1985) showed that fruiting affected the allocation of plant dry matter in strawberry plants grown in a glasshouse. At the end of their study, plants with fruit had $62 \%$ less dry matter in the roots than plants where the flowers were continually removed, $53 \%$ less dry matter in the crowns and $44 \%$ less dry matter in the leaf blades. Schaffer et al. (1986) conducted a similar experiment but found that only the leaves were affected by fruiting. The dry weight of the leaves in fruiting plants was lower than the dry weight of the leaves in deblossomed plants.

In the present experiments, there were only small differences in average seasonal fruit fresh weight among the different treatments. A review of the reports from Florida shows that planting date and source of nursery material had at best a small effect on fruit size. There was usually only a 1to $2 \mathrm{~g}$ difference in average fruit fresh weight among the different treatments (Albregts and Chandler, 1994; Albregts and Howard, 1974; Chandler et al., 1989, 1991; Locascio, 1972; Stapleton et al., 2001).

It can be concluded that the optimum time for the planting of 'Festival' strawberry in southeastern Queensland is mid-March. Lower productivity with an earlier planting was associated with the small size of the plants, whereas lower yields with later plantings were associated with the shorter growing seasons. Large plants with crown diameters from 10 to 17 $\mathrm{mm}$ yielded $17 \%$ more than the small plants with crown diameters from 6 to $10 \mathrm{~mm}$. Material from Stanthorpe in southern Queensland, a warm-growing area, was just as productive as material from Toolangi in Victoria or Kempton in Tasmania, two cool-growing areas. It is apparent that plant size is more important than nursery-growing environment in determining the productivity of 'Festival' in southeastern Queensland.

\section{Literature cited}

Albregts, E.E. and C.K. Chandler. 1994. Effect of transplant chilling and planting date on fruiting response of 4 strawberry clones. Proc. Florida State Hort. Soc. 107: 323-325.

Albregts, E.E. and C.M. Howard. 1974. Effect of planting date, plant chilling, and plant sources on 'Tioga' strawberry growth and fruiting response. Proc. Florida State Hort. Soc. 87:187-192.

Albregts, E.E. and C.M. Howard. 1977. Effect of planting date and pre-plant chilling on strawberry fruit production. Proc. Florida State Hort. Soc. 90:278-280.

Albregts, E.E. and C.M. Howard. 1980. Effect of pre-plant transplant chilling and planting date on the growth and fruiting response of 'Dover' strawberry. Proc. Florida State Hort. Soc. 93:239241.

Bish, E.B., D.J. Cantliffe, and C.K. Chandler. 2002. Temperature conditioning and container size affect early season fruit yield of strawberry plug plants in a winter, annual hill production system. HortScience 37: 762-764.

Bish, E.B., D.J. Cantliffe, G.J. Hochmuth, and C.K. Chandler. 1997. Development of containerized strawberry transplants for Florida winter production system. Acta Hort. 439:461-468.

Butler, L.M., G.F. Fernandez, and F.J. Louws. 2002. Strawberry plant growth parameters and yield among transplants of different types and from different geographic sources, grown in a plasticulture system. HortTechnology 12:100-103.

Chandler, C.K., E.E. Albregts, and C.M. Howard. 1991. Planting date affects early season strawberry production in west central Florida. Proc. Florida State Hort. Soc. 104:227-228.

Chandler, C.K., E.E. Albregts, C.M. Howard, and A. Dale. 1989. Influence of propagation site on the fruiting of three strawberry clones grown in a Florida winter production system. Proc. Florida State Hort. Soc. 102:310-312.

Chandler, C.K., D.E. Legard, D.D. Dunigan, T.E. Crocker, and C.A. Sims. 2000. 'Strawberry Festival' strawberry. HortScience 35: 1366-1367.

Durner, E.F., J.A. Barden, D.G. Himelrick, and E.B. Poling. 1984. Photoperiod and temperature effects on flower and runner development in day-neutral, June-bearing, and ever-bearing strawberries. J. Amer. Soc. Hort. Sci. 109:396-400.

Durner, E.F. and E.B. Poling. 1988. Strawberry developmental responses to photo-period and temperature: A review. Adv. Strawberry Prod. 7:6-15.

Durner, E.F. and E.B. Poling. 2000. Phytotron research investigations with conditioned 'Sweet Charlie' and 'Camarosa' plugs. Acta Hort. 513:403-408.

Durner, E.F., E.B. Poling, and E.E. Albregts. 1986. Early season yield responses of selected strawberry cultivars to photoperiod and chilling in a Florida winter production system. J. Amer. Soc. Hort. Sci. 111:53-56.

Duval, J.R., C.K. Chandler, and E. Golden. 2005. Planting date affects early season fruit yield of strawberry in a subtropical environment. J. Amer. Pomol. Soc. 59:7-12.

Forney, C.F. and P.J. Breen. 1985. Dry matter partitioning and assimilation in fruiting and deblossomed strawberry. J. Amer. Soc. Hort. Sci. 110:181-185.

Hancock, J.F. 2008. Fragaria Xananassa strawberry, p. 651-661. In: J. Janick and R.E. Paull (eds.). The encyclopedia of fruit \& nuts. CABI, Wallingford, UK.

Herrington, M.E., C.K. Chandler, J.A. Moisander, and C.E. Reid. 2007. 'Rubygem' strawberry. HortScience 42:14821483.

Johnson, C., T. Raiford, and K. Whitley. 2005. Initial crown diameter of transplants influences marketable yield components of two strawberry cultivars in annual hill production system. Intl. J. Fruit Sci. 5:23-29.

Kirschbaum, D.S., D.J. Cantliffe, R.L. Darnell, E. Bish, and C.K. Chandler. 1998. Propagation site latitude influences initial carbohydrate concentration and partitioning, growth, and fruiting of 'Sweet Charlie' strawberry (Fragaria Xananassa Duch.) transplants grown in Florida. Proc. Florida State Hort. Soc. 111:93-96.

Locascio, S.J. 1972. Influence of planting date and pre-plant chilling on yield of 'Tioga' strawberries. Proc. Fla. State Hort. Soc. 85:110-113.

MacKenzie, S.J., J.C. Mertely, and N.A. Peres. 2009. Curative and protectant activity of fungicides for control of crown rot of strawberry caused by Colletotrichum gloeosporiodes. Plant Dis. 93:815-820.

Menzel, C.M. and A. Toldi. 2010. An evaluation of containerized plants for strawberries growing in a subtropical environment. HortTechnology 20:786793.

Morrison, B. and M. Herrington. 2002. Strawberry breeding in Australia. Acta Hort. 567:125-128.

Peres, N.A., J.F. Price, W.M. Stall, C.K. Chandler, S.M. Olson, T.G. Taylor, S.A. Smith, and E.H. Simonne. 2006. Strawberry production in Florida, p. 375382. In: S.M. Olson (ed.). The vegetable 


\section{Research Reports}

production guide for Florida. Florida Coop. Ext. Serv., Inst. Food Agr. Sci., Univ. of Florida, Gainesville, FL.

Schaffer, B., J.A. Barden, and J.M. Williams. 1986. Whole plant photosynthesis and dry-matter partitioning in fruiting and deblossomed day-neutral strawberry plants. J. Amer. Soc. Hort. Sci. 111:430433.

Stapleton, S.C., C.K. Chandler, D.E. Legard, J.F. Prince, and J.C. Sumler, Jr. 2001. Transplant source affects fruiting performance and pests of 'Sweet Charlie' strawberry in Florida. HortTechnology 11:61-65.
Stewart, P.J. and K.M. Folta. 2010. A review of photoperiodic flowering research in strawberry (Fragaria spp.). Crit. Rev. Plant Sci. 29:1-13.

Vock, N. 1997. Strawberry information kit. Dept. Primary Industries, Nambour, Queensland, Australia. 